\title{
Effectiveness of Environmentally-Based Science Learning towards Environmentally-Friendly Character of Students in Coastal Area
}

\section{Elya Nusantari}

Dr, Universitas Negeri Gorontalo, Indonesia, elyanusantari@ung.ac.id

\section{Ramli Utina}

Prof., Universitas Negeri Gorontalo, Indonesia,ramli.utina.@ung.ac.id

\author{
Abubakar Sidik Katili \\ Assoc. Prof., Universitas Negeri Gorontalo, Indonesia, dikykatili@ung.ac.id \\ Yowan Tamu \\ Assoc. Prof., Universitas Negeri Gorontalo, Indonesia, yowan.tamu@ung.ac.id \\ Insar Damopolii \\ Senior Lecturer, Universitas Papua, Indonesia, i.damopoli@unipa.ac.id
}

This research aims at analyzing the effectiveness of environmentally-based science learning to improve the environmentally friendly character of the students in the coastal area. This was experimental research with one group pre-test - post-test design. A total of 83 elementary students from the coastal area participated as a sample in this research. Samples were obtained through cluster random sampling. The test was administered to collect the data on student character. Wilcoxon test was administered in this research. The result obtained $p<0.05$, where a significant increase in the environmentally friendly character of students in the coastal area was shown. This research concluded that environmentally based science learning is effective in increasing the environmentally friendly character of the students. This result was expected to contribute to the development of the environmentally friendly character of students by their teachers.

Keywords: character science education, environmental problem, environmentally friendly, students' character

\section{INTRODUCTION}

Coastal and marine ecosystems in Indonesia have generally experienced pressure from various local interests. Similar situations were shown in the coastal area of Gorontalo province as part of the Tomini Bay coastal area. The coastal areas in Gorontalo province

Citation: Nusantari, E., Utina, R., Katili, A. S., Tamu, Y., \& Damopolii, I. (2020). Effectiveness of Environmentally-Based Science Learning towards Environmentally-Friendly Character of Students in Coastal Area. International Journal of Instruction, 13(3), 233-246. https://doi.org/10.29333/iji.2020.13316a 
have many potentials, such as mangrove, seagrass, and coral reef, as the main components in the coastal ecosystem. Recently, marine resources in the coastal area have become endangered (Utina, 2017). This was due to the utilization of detonators and poisonous substances for excessive fishing. The utilization of destructive fishing methods has destroyed the coral reefs as fish habitat. Coral reefs were massively destroyed by bombing, especially cyanide bombing, to capture the coral fish (Golar, Akhbar, Umar, Rachman, Alam, \& Labiro, 2017). Further damage to the ecological functions of the coastal area is toward its ability to support the livelihood of the coastal community. Similarly, coral reefs were also destroyed by fishermen's practices to use this coral as building materials. The thorough marine ecosystem is also due to the pollution and mud sediment in the sea. Mud sediment came from gold mining in the upstream. In addition, mangrove destruction for fish ponds area has also denigrated the function of the ecosystem (Ellison, 2008). Mangrove destruction has caused the destruction of the basic habitat and destroyed the function of sea grass and coral reefs ecosystems.

People have played a role in the issues of the environment. Environmental problems are due to human activities (Özcan \& Demirel, 2019). The rapid changes in industry and technology have caused various environmental problems (Alaydin, Demirel, Altin, \& Altin, 2014). Consumptive attitude toward natural resources has caused global environmental problems (Yachina, Khuziakhmetov, \& Gabdrakhmanova, 2018). In addition, the relation with urbanization, population growth, and the diminishing open space area for the last few decades have caused a large gap between the environment and human lives (Bruyere, Wesson, \& Teel, 2012). Aguirre-Bielschowsky, Freeman, and Vass (2012) mentioned that the environment was largely influenced by cultural context, individual experience, and teaching practice in a school environment. It is a positive thing for the school to introduce environmental problems through its learning program. It is effective in developing an active attitude and minimizes the passive attitude toward the environment.

Within the education context, local resources and environmental problems are often mentioned and used in the teaching and learning process (Damopolii, Nunaki, Nusantari, \& Kandowangko, 2019; Feszterova \& Jomova, 2015). Acknowledgment of a unique experience, active participation in learning, development of positive attitude, and students' interest in science class can be increased through the administration of environmental problems in the teaching and learning process (Boyce, Mishra, Halverson, \& Thomas, 2014). To develop a positive relationship and increase students' awareness of the environment, they need to be directed to learn about their environment (Feszterová, 2014; Louv, 2005). Hokayem and Jin (2019) expect to have inspired researchers to carry out further research to promote teaching and learning using environmental problems. He expects it can be carried out through science learning within the classroom.

Within a science class, students learn the concept through scientific phenomena happening in nature. Science learning helps students to understand nature better. Science learning within the 2013 curriculum is directed toward environmental problems. When 
science learning integrated into the environment, it will give meaningful understanding for students (Dewi, Suryadarma, Wilujeng, \& Wahyuningsih, 2017). Reconstruction of science learning will develop students' good character (Khusniati, 2014). When students are able to understand science properly, it will influence increasing their good character (Rubini, Permanasari, \& Permana, 2018). Students' character is evident from their attitude toward environmental problems. One of the main principles in science learning is a positive attitude (Prabowo, 2015). Weiland and Morrison (2013) recommend integrating environmental issues into science learning. Science learning helps to increase students' analysis ability, sensitivity toward local potentials of their environment, and valuing their environment (Rahardini, Suryadarma, \& Wilujeng, 2017). When they can learn to understand nature properly, their environmentally friendly character will be better. This can be achieved through education, especially science learning.

Rokhman, Hum, \& Syaifudin, (2014) state that Indonesia needs to rethink its stands on development programs related to natural resources, human resources, and sustainable production. Good human resources will preserve natural resources. Moreover, education is the best means to improve human resources. Character education is an appropriate solution (Jeynes, 2019). Character education is related to the level of love expression, integrity, passion, and high self-discipline compared to an education program that solely focuses on learning achievement. The next important step for character education to success is involvement (Novianti, 2017). Character values have to be integrated into teaching (Suyatno, Jumintono, Pambudi, Mardati, \& Wantini, 2019). Students who understand the character's values and behaviors will naturally be good (Bridge, 2019).

Character education is currently developing science, which is aimed at optimizing the ethical behavior of the learners (Agboola \& Tsai, 2012). They reveal that character education on children, where those characters were taught through education, contributes to the learners' future. Children should be equipped with character education as early as possible, to assist them to be good citizens. Character education should be a mission that is integrated and developed in the school's daily lives (Abdullah, 2018). Abdullah studied character education through environmental hygiene. It shows that environmental problems should become the focus of attention by teaching children on these problems as early as possible.

When learners were asked about the cause of environmental problems, they responded that human interventions were mainly the cause (Aguirre-Bielschowsky, Freeman, \& Vass, 2012). Elias \& Ryan (2015) found that school as a place to learn has significantly contributed to their surroundings. When environmental problems happened, those problems are correlated with human activities and behaviors. Thus, the environmentally friendly character needs to be established in students. Environmental education was considered as an important strategy to solve environmental problems ( $\mathrm{Li}, 2018$ ). In his research, he found that learners' awareness of environmental problem supports the environmental law revision in China. The author's research focuses on general environmental problems, whereas specific problems, such as coastal area contributions, were not discussed to increase the environmentally friendly character of the students. 
Özcan \& Demirel (2019) explored the cognitive structure of secondary school students on environmental problems such as global warming, acid rain, greenhouse effect, and natural resources destruction using pictures. This research focused only on secondary students. Tonge, Ryan, Moore, \& Beckley, (2015), in their research about environmental awareness of visitors of Ningaloo Marine Park in Australia, found that environmentally friendly character was influenced by area identity. This is correlated to the visitors' commitment toward a better environment. On the other hand, Cheng, C. Wu, \& Huang (2013) found that the higher the attachment to a place, the higher the intention to behave in environmentally friendly behaviors. Their previous studies have also studied environmental character related to the environment. However, those were not focused on the coastal area ecosystem, and the samples were not the coastal community themselves, specifically students of elementary schools.

Individual awareness toward nature can also be viewed from their interaction with nature (Latysheva, Bulgakova, Sidorenko, Korenko, Khairullina, Shaidullina, \& Bayanova, 2018). The environment was very relevant and effective to be used as a supporting component in character education since the content was beneficial to increase students' ability (Pane \& Patriana 2016). The environmentally friendly character education should be nurtured as early as possible during the elementary level of education. Elementary school was an appropriate place for character education (Mak, 2014). Yachina, Khuziakhmetov, and Gabdrakhmanova (2018) have identified the unavailability of ecological programs in elementary school. Elementary school education should provide a foundation for students to develop an ecological attitude, as this will prepare them to appreciate the nature and make decisions and introduce them that nature is beautiful, especially the area where they live.

Environmentally friendly character teaching can be done by referring to the local resources and the local wisdom of the coastal area, which reflected in the way people act and behave toward the changes in their physical environment and culture (Tamalene, $\mathrm{Al}$ Muhdhar, Suarsini, \& Rochman, 2014; Utina, 2017). These local wisdom values are important to be included in the planning, implementation, and evaluation of the teaching and learning process of the students. This is to raise the awareness of elementary students in preserving their natural resources, especially the coastal resources. Katilmis, Eksi, \& Ozturk (2011) wrote that character values taught to students should be focused on creating students' involvement in academic matters and minimize irresponsible behaviors. Skaggs \& Bodenhorn (2006) argued that to ensure the effectiveness of character education, its application should be aligned with the objectives and needs of the local community. Grounded on the local problem, especially the Local Gorontalo community on environmental destruction, character education in students need to be developed, especially students who live in coastal areas in Gorontalo. By developing students' environmentally friendly character, the coastal area will be well preserved.

Environmental problems happened largely due to negative human activities. Similarly, in Gorontalo province, especially in coastal areas, the environmental destruction is also due to local people's activities. Thus, they need to start caring about their environment. The young generation, especially those in elementary school, needs to be properly 
taught to care about their environment. This research focuses on teaching the environmentally friendly character in elementary school students to increase their awareness of the preservation of their coastal environment. This research aimed to investigate the effectiveness of environmentally-based science learning in elementary school to increase students' awareness of the coastal area.

\section{METHOD}

\section{Research Design}

This was experimental research. The research design employed one group pre-test post-test (Fraenkel, Wallen, \& Hyun, 2011). This design was employed to see the effectiveness of the developed learning device. This article was part of a Research and Development research. Within this article, the researchers no longer describe the development process, as this process has already been disseminated in a national seminar. The focus of this article was the effectiveness test. The samples were given a pre-test before the learning process was implemented, and at the end of the learning process, a post-test was administered

\section{Sample}

A total of 83 elementary school students participated as a sample in this research. The samples were selected using cluster random sampling technique. There was four schools participated as the population of this research. These four schools are located within the coastal area of Gorontalo province. These four schools have met the sampling criteria due to its geographical location, i.e., schools located in coastal areas of Gorontalo province. The random sampling resulted in four classes from these four schools selected as the samples, where they were taught using the developed learning device. This developed learning device is related to environmentally friendly- based science learning. Within their science learning, environmental topics that are similar to their surroundings are inserted.

\section{Instrument and Procedures}

The instrument used was the students' book, lesson plan, student worksheet, and learning achievement test, all of which were integrated with an environmentally friendly character. Implementation of this research was initiated with coastal area natural resources potential analysis. The potential analysis is an analysis to assess the potential of an area or region. The potential of a region is explored and documented. The result of this documentation then analyzed to find out the potentials of that area to be further used as topics in science learning. The initial result through interviews showed that teachers' knowledge related to natural resources and the potential of the coastal area were low, especially on seagrass, and it is functions. Similarly, observation on the teaching process in the class, it appeared that teachers were yet to link the learning materials with the local coastal area potentials. This might have impacted on low students' knowledge on the relation between local resources and environmental preservation. The result of Focus Group Discussion with community members also shows that the local community has their local wisdom in the utilization of local resources, such as reading the earthquake, 
natural changes, moon revolution, sea depth detection, taboos and myth on going to the sea for fishing, and the fishing season for different fish. Knowledge of this local wisdom should be passed down to the next generation. Such knowledge can also be acquired through formal education, which integrated with the school curriculum to ensure it is sustainability.

From the analysis of the 2013 Curriculum, a number of the theme in natural science subjects can be further developed by including the local natural resources content. These initial studies decide to design a science learning device with local natural resources content and environmentally friendly character contents. The design stage of this learning device used the format that has been agreed by the teacher, the 2017 edition of the 2013 curriculum in a science subject. The themes/topics discussed in this research were natural resources and their destructions. The materials were packaged into stories namely: (1) Derita si Ikan Kecil Kak Nune/the suffering of Kak Nune's little fish, (2) Pengrajin Kayu yang Bijak/the wise carpenter, (3) Nonu, Pulu, Uma and (4) Tune Sang Penyelamat Padang Lamun/ Tune the seagrass hero. The themes of the materials were related to the ecosystem of the coral reefs, mangrove, and seagrass in the coastal area of Gorontalo province.

The developed device was validated by six validators (three educational and environmental experts), and a focus group discussion was carried out to strengthen the result further. The result of the validation is presented in Table 1 below.

Table 1

The Validity Test Result of the Environmentally-Based Science Learning

\begin{tabular}{llll}
\hline Learning Device & Validation & Category & Decision \\
\hline Student book & 87.66 & Highly valid & Can be used \\
Lesson plan & 88.88 & Highly valid & Can be used \\
Student worksheet & 89.00 & Highly valid & Can be used \\
Environmentally friendly character test & 86.13 & Highly valid & Can be used \\
\hline
\end{tabular}

Table 1 shows that the developed learning devices are highly valid. This means that the developed learning device can be used in the learning process. This validated learning device can further undergo the first phase of a product trial. The result of the trial has been presented at a national seminar. Within this article, the effectiveness tests were carried out to gain information on the students' environmentally friendly characters. The students learn about science with additional environmentally friendly content. The topics on the environment were inserted to see their feedback on the phenomena happening in their environment. They are tested on their environmentally friendly character using the essay test. The essay test was administered twice; one before the learning administered and one after the learning administered. The students' responses portray their character toward their environment. The pre-test and post-test are similar tests. Their responses on the test then graded based on the score in the provided rubric. The rubric score is between $0-100$. Their total score is the final score for their environmentally friendly character 


\section{Data Analysis}

The analysis to test the effectiveness of environmentally friendly-based science learning was carried out through the Wilcoxon test. The tests were administered to the score of pretest and posttest. Wilcoxon test was administered as the data have abnormal distribution. The analysis of the data used the IBM SPSS 20 software program. In addition, the n-gain test was also administered. The n-gain was administered to calculate the increase in the environmentally friendly character of the students. The n-gain categories were distributed into, low $(<.3)$, moderate $(.3-.7)$, and high $(>.7)$.

\section{FINDINGS}

This study focuses on testing the effectiveness of environmentally friendly-based science learning. The normality test of the data is presented in Table 2 . The effectiveness test is presented in Table 3. Meanwhile, the n-gain categories for each student are presented in Figure 1

Table 2

The Result of the Normality Test of the Environmentally Friendly Character Data

\begin{tabular}{llllll}
\hline Test & $\mathrm{N}$ & Mean & SD & Sig. & Normal Distribution \\
\hline Post-test & 83 & 81.54 & 11.26 & .438 & Yes \\
\hline Pre-test & 83 & 21.27 & 20.02 & .002 & No \\
\hline
\end{tabular}

Table 2 shows that the pre-test data have abnormal distribution. The value of sig. was $.002<.05$. Further, the post-test data shows a normal distribution, where the sig was $.438>.05$. As one of the data have abnormal distribution, and then further nonparametric analysis using the Wilcoxon test was administered.

Table 3

Wilcoxon Test of the Students' Environmentally Friendly Character

\begin{tabular}{llrrrrr}
\hline & $\mathrm{N}$ & Mean Rank & Sum of Ranks & $\mathrm{Z}$ & \multicolumn{1}{c}{ Sig. } \\
\hline \multirow{3}{*}{ Pre-test - Post-test } & Negative Ranks & $0^{\mathrm{a}}$ & .00 & .00 & $-7.918^{\mathrm{b}}$ & .000 \\
\cline { 2 - 7 } & Positive Ranks & $83^{\mathrm{b}}$ & 42.00 & 3486.00 & & \\
\cline { 2 - 7 } & Ties & $0^{\mathrm{c}}$ & & & & \\
\cline { 2 - 4 } & 83 & & & & \\
\hline
\end{tabular}

Table 3 shows that there are 83 students whose environmentally friendly character is measured. These 83 samples show an increase in environmentally friendly characters before and after the treatment. No students who experience a decrease in an environmentally friendly character. The sig. value shows that $.000<.05$. This means that there is a significant influence of environmentally friendly-based science learning toward the student's environmentally friendly character. This influence also means that environmentally friendly-based science learning is effective in developing the students' environmentally friendly character, especially the students that reside in coastal areas. Figure 1 below shows the percentage of achievement in each n-gain category. 


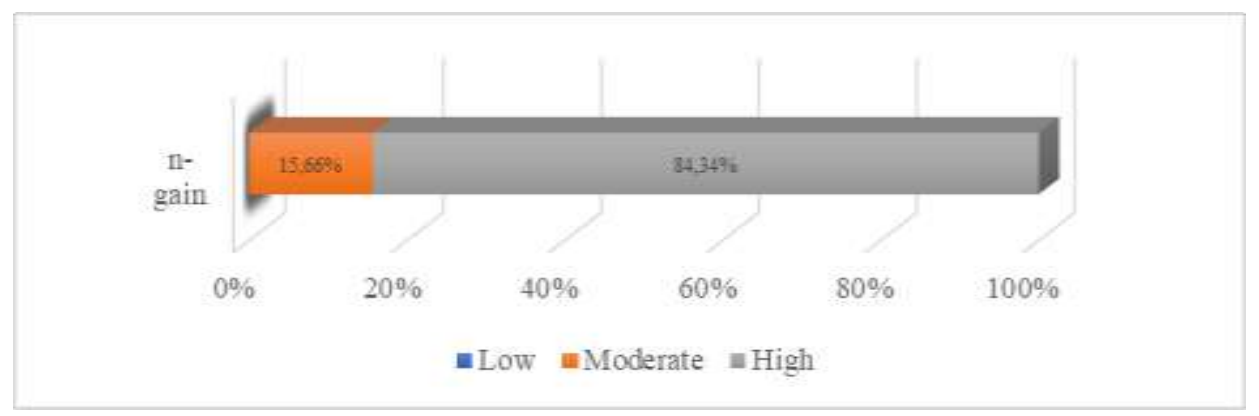

Figure 1

N-gain Achievement Category of an Environmentally Friendly Character

Figure 1 reveals that there are $84.34 \%$ of the students whose n-gain category is high. There are only $15.66 \%$ of the students whose n-gain category is moderate. No, students achieve a low n-gain category. This result indicated that science learning is effective in increasing the environmentally friendly character of the students. Figure 1 shows that largest proportion of the students achieves a high n-gain category on their environmentally friendly character.

\section{DISCUSSION}

This research shows that environmentally friendly-based science learning can increase the environmentally friendly character of the students in the coastal area. The designed learning device met the validity and effectiveness test. Pandiangan, Sanjaya, Gusti, \& Jatmiko (2017) urged that the designed learning had to fulfill certain objectives and characteristics, as well as met the validity and effectiveness criteria. The designed learning had specific objectives and characteristics, namely environmentally friendlybased science learning, to develop environmentally friendly characters of the students.

Through this environmentally friendly character, students will be enthusiastic about preserving the coastal ecosystem. Environmentally friendly attitude also preserve the lives of millions of people in developing countries with their tropical beaches (DahdouhGuebas and Koedam, 2008). Highly educated communities tend to be more aware of environmental conservation than less-educated communities. The community is those who have a high awareness of environmental problems, especially those related to the sustainability of their lives in the future (Abdullah, Said, \& Omar, 2014). The learning that has been implemented in school was based on the local character scores. Thus, the learning process can bring optimum changes in behavior. In this research, the local culture of the coastal community was utilized optimally to develop the environmentally friendly character of the students as those who will carry out the preservation of the coastal ecosystem. The well-preserved coastal ecosystem will ensure the livelihoods of millions of creatures within the ecosystem and maintain the balance of the ecosystem.

Implementation of this environmentally friendly character in learning was carried out through introduction, observation, understanding, and discovery to internalized students' comprehension of the coastal ecosystem. These learning patterns made students able to 
discover the concepts and local coastal phenomena, contextually, and realistically. Learning activities through a scientific approach, namely the learning process designed to encourage students' active participation in constructing concepts and principles of learning through scientific processes toward certain phenomena or events (Utina, 2017). The previous research had also found that the development of local coastal areas-based learning devices had several advantages, such as the topics discussed had local content on the diversity of local creatures in the coastal areas. Thus, students can learn contextually and realistically (Nusantari \& Lihawa, 2017).

In our research was found that the increase in the environmentally friendly character was of high category. It implies that to develop environmentally friendly character, environmental problems presented to the students should be the problems that are happening around them. In this research, students in coastal areas were taught and presented with coastal problems that are happening in their surroundings. However, they were yet to understand and aware of those problems. This finding echoed the research by Feszterova and Jomova (2015), where they found that students who were taught using environmental problems positively showed an increase of learning on their awareness toward environmental problems. In addition, Bruyere, Wesson, and Teel (2012) had gained feedback from after-school instructors as the sample in their research. One of the instructors revealed that he loved to teach science and conservation as he lives and grows up in an environment where there were a river, animals, muds, etc., in which, all of those provided students with learning as well as opportunities to gain happiness, compared to watching TV or playing games. Through these activities, students can understand and respect nature. Meanwhile, in this research, students' respect toward the coastal environment was shown by their responses on the questions asked by the teacher, such as cited in the following question $(\mathrm{Q})$ and answer (A) with the student:

$Q_{1}$ : you were swimming with your friends in the sea, one of your friends stepped on the coral reefs. How would you react to this? Explain!

$A_{1}$ : he should not step on the coral reef. If the coral reefs are destroyed, the fish will die.

$Q_{2}$ : technology has been rapidly changing; some fishermen use a fish bomb to capture more fish. Do you agree with this method of fishing? Explain!

$A_{2}$ : No. because fish bombing destroys coral reefs, and when coral reefs are destroyed, fish no longer have homes.

By looking at the student's responses on $\mathrm{Q}_{1} \mathrm{~A}_{1}$ and $\mathrm{Q}_{2} \mathrm{~A}_{2}$, it is obvious that student knew that stepping on coral reefs are destructive action, especially for the coastal area. It was clear to the students that destructive activities should be avoided in order to preserve their coastal area. Human interactions with the environment were depicted by the action to step on the coral reefs. An individual who was aware of the problem could grow perception, and appreciation toward the environment by looking at human interaction with nature (Gifford \& Nilsson, 2014). Good responses from the student showed the existence of a good attitude of the learners to preserve their environment. Good 
awareness of the environment is intended to minimize the negative influence of human interaction on the environment (Kim, 2012). The utilization of fish bomb by fishermen yielded a good response from the students, where he said that the fish bomb destroys coral reefs, and ultimately destroys the home of the fish. Preserving the environment is a form of environmental awareness. A well-preserved nature with all its diversity will bring a good impact on the community, especially the coastal area community.

In an environmentally friendly-based science class, students appeared comfortable, and they showed a good result when being asked about their awareness of their environment. The learning situation in these classes was enjoyable; they were able to comprehend the character values taught in the class, such as compassion, willingness to act, and selfcontrol (Sugiyo \& Purwastuti, 2017). Students' self-control was portrayed through their responses not to conduct activities that destroyed the coastal areas, their passions toward preserving the coastal environment, and their compassion was shown by the responses not to allow the destruction of the coastal area as it made other creatures (fish) lost their home.

The meta-analysis by Jeynes (2019) founded that overall, character education had a larger impact on secondary school students than those in elementary school. The largest impact of character education is for secondary school students, followed by high school students, and the least effect was on elementary school students. The result of this present research was that science learning in elementary school showed an effect on the increase of character value, especially environmentally friendly character. The n-gain in this research was high, with the average achievement on the environmentally friendly character were within the very good category. This finding reveals that character education value at the primary school level can gain a high score. The environmentally friendly character is one of the characters that can be properly developed in primary school.

Further implementation of this research is essential in coordination with educational authority in the regions, especially in the coastal area, as the main stakeholder in human resource development. Educational offices in the regions with coastal areas in Gorontalo province are expected to incorporate the result of this research, as Gorontalo has a strategic role in formulating an appropriate strategy to develop environmentally friendly characters in schools. The result of this research is essential to be followed up by codesigning wider dissemination of the result of this research together with educational departments, planning agencies, researchers (university) in regency levels in Gorontalo. The result can be disseminated into schools located in coastal areas. Therefore, the implementation of environmentally friendly character by incorporating the local wisdom values of a region into a learning process in a school can create an educational system, which able to prepare future qualified human resources who will preserve the coastal ecosystem by observing the character values, good morals, and ethics.

\section{CONCLUSION AND SUGGESTION}

This research concluded that environmentally friendly-based science learning significantly effective in increasing the environmentally friendly character of the 
students. There were $83.34 \%$ of the students who achieve a high increase in their environmentally friendly character. Elementary school students in the coastal area experienced an increase of environmental awareness and cared toward the preservation of their coastal area. The results of this research reveal that character education, especially environmentally friendly character, was very appropriate to be taught as early as possible to students of elementary school level. Elementary school teachers in the coastal area can utilize various environmental problems in their area as learning resources to improve the environmentally friendly character of their students. This study significantly contributes to character education, especially students in primary school. The character that can be developed is environmentally friendly.

The limitation of this research is that it was still focused on one character only, an environmentally friendly character. There are various characters that can be increased, especially for learners in the coastal area. In the future, it is expected that other research can be grounded on environmental problems in the coastal area to teach and develop other good characters and even can teach learners to carry out a field visit to observe the attitude and actions of the learners on the observed problems. Other researchers can also use a control class to compare it with the treatment class. To protect and preserve the environment, the environmentally friendly character is one of the characters that need to be developed, especially through government support, to preserve the environment, specifically the coastal area.

\section{ACKNOWLEDGEMENT}

We would like to express our gratitude to related parties that provided support and assistance for this research to mention but a few, the local government of Pohuwato District, Boalemo District, and Northern Gorontalo District. We would like to extend our gratitude to the Office of Research and Community Service of Universitas Negeri Gorontalo; the Directorate General of Higher Education of the Ministry of Research, Technology, and Higher Education, the Republic of Indonesia for providing us with financial support through PTUPT (Applied Research of University) research scheme..

\section{REFERENCES}

Abdullah, A. (2018). Cultivating morals students through character education : a Case study. Journal of Education and Learning (EduLearn), 12(3), 457-463.

Abdullah, K., Said, A. M., \& Omar, D. (2014). Community-based conservation in managing mangrove rehabilitation in Perak and Selangor. Procedia - Social and Behavioral Sciences, 153, 121-131.

Agboola, A., \& Tsai, K. C. (2012). Bring character education into classroom. European Journal of Educational Research, 1(2), 163-170.

Aguirre-Bielschowsky, I., Freeman, C., \& Vass, E. (2012). Influences on children's environmental cognition: a comparative analysis of New Zealand and Mexico. Environmental Education Research, 18(1), 91-115.

Alaydin, E., Demirel, G., Altin, S., \& Altin, A. (2014). Environmental knowledge of 
primary school students: Zonguldak (Turkey) example. Procedia-Social and Behavioral Sciences, 141, 1150-1155.

Boyce, C. J., Mishra, C., Halverson, K. L., \& Thomas, A. K. (2014). Getting students outside: Using technology as a way to stimulate engagement. Journal of Science Education and Technology, 23(6), 815-826.

Bridge, O. B. (2019). New perspectives on young children's moral education: developing character through a virtue ethics approach. Journal of Education for Teaching, 45(2), 236-238.

Bruyere, B. L., Wesson, M., \& Teel, T. (2012). Incorporating environmental education into an urban after-school program in New York city. International Journal of Environmental and Science Education, 7(2), 327-341.

Cheng, T.-M., C. Wu, H., \& Huang, L.-M. (2013). The influence of place attachment on the relationship between destination attractiveness and environmentally responsible behavior for island tourism in Penghu, Taiwan. Journal of Sustainable Tourism, 21(8), 1166-1187.

Dahdouh-Guebas, F., \& Koedam, N. (2008). Long-term retrospection on mangrove development using transdisciplinary approaches: A review. Aquatic Botany, 89(2), 80-92.

Damopolii, I., Nunaki, J. H., Nusantari, E., \& Kandowangko, N. Y. (2019). Integrating local resources into inquiry-based teaching materials to training students' science process skills. AIP Conference Proceedings, 2120(July), 060003

Dewi, I. P. M., Suryadarma, I. G. P., Wilujeng, I., \& Wahyuningsih, S. (2017). The effect of science learning integrated with local potential of wood carving and pottery towards the junior high school students' critical thinking skills. Jurnal Pendidikan IPA Indonesia, 6(1), 103-109.

Elias, M. J., \& Ryan, D. P. (2015). The essential convergence of social-emotional learning, character, and school culture and climate for our students' success. Tipica, Boletín Electrónico de Salud Escolar, 11(2), 186-102.

Ellison, A. M. (2008). Mangrove ecology-applications in forestry and costal zone management. Aquatic Botany, 89(2), 77.

Feszterová, M. (2014). Dangerous substances and processes: consideration of the subject within the educational process. Procedia-Social and Behavioral Sciences, 116, 1176-1180.

Feszterova, M., \& Jomova, K. (2015). Character of innovations in environmental education. Procedia-Social and Behavioral Sciences, 197, 1697-1702.

Fraenkel, J. R., Wallen, N. E., \& Hyun, H. H. (2011). How to design and evaluate research in education. New York: McGraw-Hill Humanities/Social Sciences/Languages.

Gifford, R., \& Nilsson, A. (2014). Personal and social factors that influence proenvironmental concern and behaviour: A review. International Journal of Psychology, 
49(3), 141-157.

Golar, Akhbar, Umar, H., Rachman, I., Alam, A. S., \& Labiro, E. (2017). The poverty assessment based on subjective criteria: a case study of the rural community near the protected forest in central Sulawesi. Australian Journal of Basic and Applied Sciences, $11(9), 22-30$.

Hokayem, H., \& Jin, H. (2019). Enhancing Environmental literacy in K-12 science classrooms. EURASIA Journal of Mathematics, Science and Technology Education, $15(6), 1-2$.

Jeynes, W. H. (2019). A meta-analysis on the relationship between character education and student achievement and behavioral outcomes. Education and Urban Society, 5l(1), $33-71$.

Katilmis, A., Eksi, H., \& Ozturk, C. (2011). Efficiency of social studies integrated character education program. Educational Sciences: Theory and Practice, 11(2), 854859.

Khusniati, M. (2014). Model pembelajaran sains berbasis kearifan lokal dalam menumbuhkan karakter konservasi. Indonesian Journal of Conservation, 3(1), 67-74.

Kim, A. K. (2012). Determinants of tourist behaviour in coastal environmental protection. Tourism Geographies, 14(1), 26-49.

Latysheva, V. V, Bulgakova, V. O., Sidorenko, G. G., Korenko, J. M., Khairullina, E. R., Shaidullina, A. R., \& Bayanova, A. R. (2018). Subjective environmental attitude features to nature of specially protected areas employees. Ekoloji Dergisi, 27(106), $1801-1808$.

Li, Y. (2018). Study of the effect of environmental education on environmental awareness and environmental attitude based on environmental protection law of the people's republic of China. EURASIA Journal of Mathematics, Science and Technology Education, 14(6), 2277-2285.

Louv, R. (2005). Last child in the woods: saving out children from the nature-deficit disorder. Chapel Hill, NC: Algonquin Books.

Mak, W. S. (2014). Evaluation of a moral and character education group for primary school students. Discovery - SS Student Ejournal, 3, 142-164.

Novianti, N. (2017). Teaching character education to college students using Bildungsromans. International Journal of Instruction, 10(4), 255-272.

Nusantari, E., \& Lihawa, A. (2017). Developing of biology learning book with lokal potential of living thing diversity topic for SMP students. IInternational Journal of Advanced Biotechnology and Research, 4(11), 4137-4148.

Özcan, H., \& Demirel, R. (2019). Ortaokul öğrencilerinin çevre sorunlarina yönelik bilişsel yapilarinin çizimleri araciliğiyla incelenmesi. Başkent University Journal of Education, 6(1), 68-83. 
Pandiangan, P., Sanjaya, M., Gusti, I., \& Jatmiko, B. (2017). The validity and effectiveness of physics independent learning model to improve physics problem solving and self-directed learning skills of students in open and distance education systems. Journal of Baltic Science Education, 16(5), 651-665.

Prabowo, S. A. (2015). The effectiveness of scientific based learning towards science process skill mastery of PGSD students. Jurnal Pendidikan IPA Indonesia, 4(1), 15-19.

Rahardini, R. R. B., Suryadarma, I. G., \& Wilujeng, I. (2017). The effect of science learning integrated with local potential to improve science process skills. AIP Conference Proceedings, 1868, 080008.

Rokhman, F., Hum, M., \& Syaifudin, A. (2014). Character education for golden generation 2045 (National character building for Indonesian golden years). ProcediaSocial and Behavioral Sciences, 141, 1161-1165.

Rubini, B., Permanasari, A., \& Permana, I. (2018). Building character through science learning with scientific literacy based. IOP Conference Series: Materials Science and Engineering, 012030.

Skaggs, G., \& Bodenhorn, N. (2006). Relationships between implementing character education, student behavior, and student achievement. Journal of Advanced Academics, $18(1), 82-114$

Sugiyo, R., \& Purwastuti, L. A. (2017). Local wisdom-based character education model in elementary school in Bantul Yogyakarta Indonesia. Sino-US English Teaching, 14(5), 299-308.

Suyatno, Jumintono, Pambudi, D. I., Mardati, A., \& Wantini. (2019). Strategy of values education in the indonesian education system. International Journal of Instruction, 12(1), 607-624.

Tamalene, M. M., Al Muhdhar, M. H. I., Suarsini, E., \& Rochman, F. (2014). The practice of local wisdom of Tobelo Dalma (Togutil) tribal community in forest conservation in Halmahera, Indonesia. Int J Plant Res, 4(4A), 1-7.

Tonge, J., Ryan, M. M., Moore, S. A., \& Beckley, L. E. (2015). The effect of place attachment on pro-environment behavioral intentions of visitors to coastal natural area tourist destinations. Journal of Travel Research, 54(6), 730-743.

Utina, R. (2017). Ecological intelligence of coastal community on biodiversity conservation (Case Study of Bajau Coastal Communities, Gorontalo). Metamorfosa: Journal of Biological Sciences, 4(1), 54-57.

Weiland, I. S., \& Morrison, J. A. (2013). The integration of environmental education into two Elementary preservice science methods course: A content-based snd a methodbased approach. Journal of Science Teacher Education, 24(6), 1023-1047.

Yachina, N. P., Khuziakhmetov, A. N., \& Gabdrakhmanova, R. G. (2018). Formation and development of the regional system of continuous environmental education of a teacher. Ekoloji Dergisi, 27(106), 1315-1322. 